\title{
A LITERATURE REVIEW ON EFFICIENT PLANT LAYOUT DESIGN
}

\author{
Sanjeev B. Naik \\ Assistant Professor, Department of Mechanical Engineering \\ Walchand Institute of Technology, Solapur, India \\ Dr. Shrikant Kallurkar \\ Principal, Atharv College of Engineering, Malad, Mumbai, India
}

\begin{abstract}
Facility layout design involves a systematic physical arrangement of different departments, work stations, machines, equipments, storage areas and common areas in a manufacturing industry. In today's competitive global environment, the optimum facility layout has become an effective tool in cost reduction by enhancing the productivity. It has become very essential to have a well organised plant layout for all available resources in an optimum manner to achieve the maximum returns from the capacity of facilities. To achieve the optimisation objectives a lot of techniques are developed by many researchers in the domain area. The objective of this paper is to review the contributions in the field not only for plant layout but re-layout also.
\end{abstract}

Key words: Facility layout, optimum facility layout, re-layout

Cite this Article: Sanjeev B. Naik and Shrikant Kallurkar, A Literature Review on Efficient Plant Layout Design, International Journal of Industrial Engineering Research and Development, 7(2), 2016, pp. 43-51. https://iaeme.com/Home/issue/IJIERD?Volume=7\&Issue $=2$

\section{INTRODUCTION}

A facility layout is an integration of the physical arrangement of departments, workstations, machines, equipments, materials, common areas etc, within an existing or proposed industry. Most plant layouts are designed properly for the initial conditions of the business. However these layouts provide many bottlenecks during growth period. Hence as long as capacity grows, it has to adapt the internal and external changes for which a re-layout is necessary. The reasons for a re-layout are due to changes in production volume, changes in process and technology and changes in the product.

The frequency of re-layout depends upon requirement of the present situation. Hence facility layout design is a continuous iterative process based upon the changing constraints of dynamic environment. So optimization of facility layout is situation 
based requirement of the industry, The symptoms that allow the need for a re-layout are congestion and bad utilization of space, excess stock in process at the facility, high material handling distances, bottleneck at workstations, idle time of facilities and workers, labour anxiety and discomfort, accidents and difficulty in controlling operations and personnel.

\section{TOOLS FOR OPTIMIZING LAYOUT DESIGN: HEURISTIC METHODS}

The most well known heuristic methods in optimizing layout design are Tabu Search (TS), Simulated Annealing (SA), and Genetic Algorithms (GA). The popularity of these heuristics has flourished in recent years and several published studies can be found in the literature. Arostegui, et al [5] classify heuristics methods into tailored and general. While tailored heuristics have a limited applicability to a specific problem while general algorithms define a strategy for obtaining approximate solutions and thus are widely applicable to various forms of combinatorial optimization problems.

Tabu Search (TS) is a mathematical optimization method, belonging to the class of local search techniques [5]. Tabu search enhances the performance of a local search method by using memory structures. Once a potential solution has been determined, it is marked as taboo, so that the algorithm does not visit that possibility repeatedly.

A genetic algorithm (GA) is a search technique used in computing to find exact or approximate solutions to optimization and search problems [5]. Genetic algorithms are categorized as global search heuristics. Genetic algorithms are a particular class of evolutionary algorithms (EA) that use techniques inspired by evolutionary biology such as inheritance, mutation, selection, and crossover [7]. Simulated annealing (SA) is a generic probabilistic metaheuristic for the global optimization problem of applied mathematics, namely locating a good approximation to the global minimum of a given function in a large search space [5]. It is often used when the search space is discrete. For certain problems, simulated annealing may be more effective than exhaustive enumeration, provided that the goal is merely to find an acceptably good solution in a fixed amount of time, rather than the best possible solution [7].

\section{SIMULATION TECHNIQUE}

Simulation technique is also recommended in the facility planning analysis. Nica, et al [25] reported that queuing phenomena of parts before entering assembly area is in uncertainty arrival time. Simulation is an appropriate tool to help the designer to define the storage spaces of assembly system in this stochastic situation. In this research, a concept of ordered parts buffer is proposed for sequencing parts arrived in the assembly process by robot systems. Simulation based on experimental design is developed by Ekren and Ornek [9] for typical manufacturing job-shop system. They investigated the effects of layout types and their interactions with other manufacturing parameters that can affect performance of the system.

A simulation model has been developed as an analysis tool for line reconfiguration to accommodate the future demand fluctuation. Line balancing becomes the main issue in the research and fuzzy knowledge base of technique was proposed to help define more realistic scenarios [30]. The necessity of sequence coordination within a complex assembly system is reported. This is due to the fact that the complex assembly system generally includes preassembly section for part preparation and this can only be determined by computer aided simulation. 
Simulation tools that commonly used in facility planning are Arena [9], QUEST [24], IGRIP [24], Pro Model [35] and Witness [31]. Another tool that can be used in layout simulation is Flexsim software. Flexsim is discrete event simulation software, used for evaluating, planning or designing manufacturing, warehousing, logistics and other operational and strategic situations [11]. The limitation of many software is they only provide the two dimensional visualization (2D), which is not easy to visualise, understand and evaluate. Flexsim provides the three dimensional (3D) visualization. Flexsim software helps researchers to test multiple alternatives in a short time without any risk, disruption and expenses.

\section{A SUMMARY OF WORK DONE BY RESEARCHES}

Table 1

\begin{tabular}{|c|c|c|c|}
\hline SL.No & Title and Author & Methodology & Finding \\
\hline 01 & $\begin{array}{l}\text { Layout design for Low } \\
\text { capacity manufacturing Line } \\
\text { - A case study } \\
\text { Flippo De Carlo et.al }{ }^{10}\end{array}$ & Empirical & $\begin{array}{l}\text { In the present work, the results of } \\
\text { a fashion manufacturing line re- } \\
\text { layout were compared by } \\
\text { analysing the current situation } \\
\text { with the solutions provided by a } \\
\text { homemade company design, both } \\
\text { through a systematic layout } \\
\text { planning approach and a lean } \\
\text { reengineering activity, }\end{array}$ \\
\hline 02 & $\begin{array}{l}\text { A Heuristic procedure for } \\
\text { the integrated facility layout } \\
\text { design and flow assignment } \\
\text { problem } \\
\text { Ali Taghavi et.al }{ }^{02}\end{array}$ & $\begin{array}{l}\text { Proposed a novel } \\
\text { integrated heuristic } \\
\text { procedure based on a } \\
\text { perturbation algorithm } \\
\text { and sequential location } \\
\text { heuristic. }\end{array}$ & $\begin{array}{l}\text { Performed the experimental study } \\
\text { to assess the performance of the } \\
\text { proposed procedure .The } \\
\text { experimental results demonstrate } \\
\text { that proposed heuristic procedure } \\
\text { is both efficient and effective in } \\
\text { identifying quality solutions. }\end{array}$ \\
\hline 03 & $\begin{array}{l}\text { A genetic algorithm with the } \\
\text { heuristic procedure to solve } \\
\text { the multi-line layout } \\
\text { problem } \\
\text { Amir Sadrzadeh }^{03}\end{array}$ & $\begin{array}{l}\text { The paper presents a } \\
\text { Genetic Algorithm- } \\
\text { based meta heuristic to } \\
\text { solve FLP }\end{array}$ & $\begin{array}{l}\text { The efficiency of the proposed } \\
\text { method has been proved through } \\
\text { solving examples and comparing } \\
\text { results with other genetic } \\
\text { algorithm, CRAFT algorithm }\end{array}$ \\
\hline 04 & $\begin{array}{l}\text { Using Simulation for } \\
\text { Facility Design: A Case } \\
\text { Study } \\
(\text { Greasley, 2008) })^{13}\end{array}$ & $\begin{array}{l}\text { A discrete event } \\
\text { simulation model } \\
\text { was developed and used } \\
\text { to estimate } \\
\text { the storage area } \\
\text { required for a proposed } \\
\text { overseas textile } \\
\text { manufacturing facility. }\end{array}$ & $\begin{array}{l}\text { It was found that the simulation } \\
\text { was able to achieve this because of } \\
\text { its ability to both store attribute } \\
\text { values and to show queuing levels } \\
\text { at an individual product level. It } \\
\text { was also found that the process of } \\
\text { undertaking the simulation project } \\
\text { initiated useful discussions } \\
\text { regarding the operation of the } \\
\text { facility. }\end{array}$ \\
\hline 05 & $\begin{array}{l}\text { A methodology for solving } \\
\text { the unequal area facility } \\
\text { layout problem using }\end{array}$ & $\begin{array}{l}\text { A mixed binary } \\
\text { nonlinear programming } \\
\text { model is formulated }\end{array}$ & $\begin{array}{l}\text { In addition to the distance } \\
\text { measure, the impact of geometry } \\
\text { or the shape of the departments is }\end{array}$ \\
\hline
\end{tabular}




\begin{tabular}{|c|c|c|c|}
\hline & $\begin{array}{l}\text { distance and shape based } \\
\text { measures R. Logendran } \\
\text { et.al }^{26}\end{array}$ & & $\begin{array}{l}\text { quantified in the formulation of the } \\
\text { model. A higher level heuristic } \\
\text { solution algorithm, based on a } \\
\text { concept of " Tabu search" is } \\
\text { proposed and the results are } \\
\text { compared with the published } \\
\text { alternatives in the problem area } \\
\text { and has demonstrated the } \\
\text { effectiveness of the proposed } \\
\text { method. }\end{array}$ \\
\hline 06 & $\begin{array}{l}\text { An alternative multiple } \\
\text { attribute decision making } \\
\text { methodology for solving } \\
\text { optimal facility layout } \\
\text { design selection problems } \\
\text { K.D.Maniya et.al }{ }^{20}\end{array}$ & $\begin{array}{l}\text { The proposed } \\
\text { methodology is based } \\
\text { on Preference selection } \\
\text { index (PSI) }\end{array}$ & $\begin{array}{l}\text { In the proposed methodology } \\
\text { appropriate facility design is } \\
\text { selected for a given application. } \\
\text { Two different types of facility } \\
\text { layout design selection problems } \\
\text { are examined to demonstrate, } \\
\text { validate and to check the reliability } \\
\text { of proposed methodology. It is } \\
\text { concluded that FLP design } \\
\text { selection methodology based on } \\
\text { PSI method is simple, logical and } \\
\text { more appropriate. }\end{array}$ \\
\hline 07 & $\begin{array}{l}\text { An Empirical } \\
\text { Comparison of Tabu } \\
\text { Search, Simulated } \\
\text { Annealing, and Genetic } \\
\text { Algorithms for Facilities } \\
\text { Location Problems. } \\
\text { (Arostegui et al, 2006) }\end{array}$ & $\begin{array}{l}\text { Compare the relative } \\
\text { performance of Tabu } \\
\text { Search (TS), Simulated } \\
\text { Annealing (SA), and } \\
\text { Genetic Algorithms } \\
\text { (GA) on various } \\
\text { Facilities Location } \\
\text { Problems (FLP). }\end{array}$ & $\begin{array}{l}\text { The results indicate that TS shows } \\
\text { very good performance in most } \\
\text { cases. The performance of } \\
\text { SA and GA are more partial to } \\
\text { problem type and the criterion } \\
\text { used. Thus, in general it may } \\
\text { conclude that TS should be tried } \\
\text { first to the extent that it always } \\
\text { yields as good or better results and } \\
\text { is easy to develop and implement. }\end{array}$ \\
\hline 08 & $\begin{array}{l}\text { Genetic Algorithms for } \\
\text { Integrating Cell Formation } \\
\text { with Machine Layout and } \\
\text { Scheduling. } \\
(\text { Xiaodan et al, 2007) }\end{array}$ & $\begin{array}{l}\text { Proposed a new } \\
\text { approach to } \\
\text { concurrently make the } \\
\text { cell formation } \\
\text { (CF), group layout (GL) } \\
\text { and group } \\
\text { scheduling (GS) } \\
\text { decisions for a } \\
\text { successful Cellular } \\
\text { manufacturing } \\
(\mathrm{CM}) \text {. A conceptual } \\
\text { framework and } \\
\text { mathematical model, } \\
\text { which integrates } \\
\text { these decisions, are } \\
\text { proposed }\end{array}$ & $\begin{array}{l}\text { The result of this study indicate } \\
\text { that: } \\
\text { (1) The concurrent approach often } \\
\text { found better solutions than the } \\
\text { sequential one. } \\
\text { (2) With the proposed heuristic } \\
\text { operators, the hierarchical genetic } \\
\text { algorithm (HGA) procedure } \\
\text { performed better than without } \\
\text { them. A hierarchical genetic } \\
\text { algorithm (HGA) is developed to } \\
\text { solve the integrated cell design } \\
\text { problem. Two heuristic operators } \\
\text { are proposed to enhance its } \\
\text { computational performance. }\end{array}$ \\
\hline 09 & $\begin{array}{l}\text { A Study on Facility } \\
\text { Planning in }\end{array}$ & $\begin{array}{l}\text { Comparing two } \\
\text { alternative design of }\end{array}$ & $\begin{array}{l}\text { This paper found that } \mathrm{U} \text {-shape } \\
\text { flow pattern design has increase } \\
\text { the efficiency utilization of labour, }\end{array}$ \\
\hline
\end{tabular}




\begin{tabular}{|c|c|c|c|}
\hline & $\begin{array}{l}\text { Manufacturing Process } \\
\text { Using Witness. } \\
\left(_{\text {Roslin } \text { et al, 2008) }}^{31}\right.\end{array}$ & $\begin{array}{l}\text { layout: U-shape and S- } \\
\text { shape. } \\
\text { The study is conducted } \\
\text { in Dinamika Pelumas } \\
\text { Sdn. Bhd. Simulation } \\
\text { tool using Witness } \\
\text { software. }\end{array}$ & $\begin{array}{l}\text { equipment, space and reduces idle } \\
\text { time. }\end{array}$ \\
\hline 10 & $\begin{array}{l}\text { Metaheuristic methods } \\
\text { for a class of the facility } \\
\text { Layout problem. } \\
(\text { Alvarenga } \text { et al, 2000) }\end{array}$ & $\begin{array}{l}\text { Comparison of } \\
\text { simulated annealing } \\
\text { (SA) and Tabu Search } \\
\text { (TS). }\end{array}$ & $\begin{array}{l}\text { Both methods produced the known } \\
\text { optimal solution for a facility } \\
\text { layout problem set with high } \\
\text { frequency and low computation } \\
\text { time. }\end{array}$ \\
\hline 11 & $\begin{array}{l}\text { Solving the failure-to-fit } \\
\text { problem for plant layout } \\
\text { by changing department } \\
\text { shapes and sizes. } \\
(\text { Lin } \text { et al, 1996) })^{28}\end{array}$ & $\begin{array}{l}\text { Apply Artificial } \\
\text { intelligence (AI) to } \\
\text { FLP }\end{array}$ & $\begin{array}{l}\text { Artificial intelligence could solve } \\
\text { the scenario of failure-to- fit } \\
\text { solutions, when no feasible layouts } \\
\text { are generated. }\end{array}$ \\
\hline 12 & 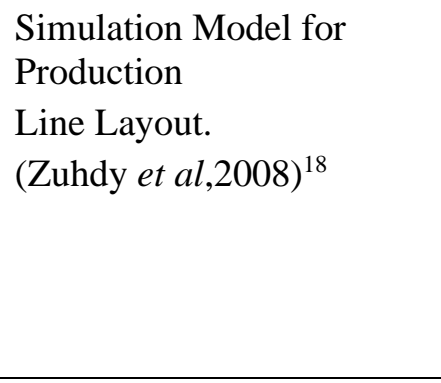 & $\begin{array}{l}\text { Existing layout is } \\
\text { evaluated by } \\
\text { Using Pro model } \\
\text { software by } \\
\text { Integrating Process } \\
\text { layout, constant } \\
\text { period scheduling and } \\
\text { Short Processing time. }\end{array}$ & $\begin{array}{l}\text { This paper proved that the } \\
\text { simulation model is capable to } \\
\text { predict the capacity of initial } \\
\text { system and test the proposed } \\
\text { design. }\end{array}$ \\
\hline 13 & $\begin{array}{l}\text { Design and Analysis of a } \\
\text { Virtual } \\
\text { Factory Layout. } \\
\text { (Iqbal and Hashmi,2001) }^{18}\end{array}$ & $\begin{array}{l}\text { All production } \\
\text { machines created in } \\
\text { AutoCAD and imported } \\
\text { to 3D } \\
\text { Studio Max software. } \\
\text { Layout problem was } \\
\text { visualized and } \\
\text { modified by applying } \\
\text { Facility } \\
\text { Layout Problem (FLP) } \\
\text { solving } \\
\text { techniques. }\end{array}$ & $\begin{array}{l}\text { Virtual factory layout helps in } \\
\text { evaluating plant layout before } \\
\text { actually building them and assists } \\
\text { in avoiding the cost involved in } \\
\text { doing physical re-layout. By } \\
\text { virtual factory layout, a designer } \\
\text { can have feel of the actual setting } \\
\text { of the factory, easy to visualize, } \\
\text { understand and evaluate. Re- } \\
\text { location of the machine can be } \\
\text { done such that the material } \\
\text { handling cost reduced as well } \\
\text { as the bottleneck removed. }\end{array}$ \\
\hline 14 & $\begin{array}{l}\text { Layout Design in Group } \\
\text { Technology Manufacturing } \\
(\text { Hassan, 1994) }\end{array}$ & Literature review & $\begin{array}{l}\text { A review and consolidation of the } \\
\text { emerging literature in the GT } \\
\text { layout and a suggestion framework } \\
\text { of analysis for developing the GT } \\
\text { layout. }\end{array}$ \\
\hline 15 & $\begin{array}{l}\text { Advances in Discrete } \\
\text { Material Handling System } \\
\text { Design. (Rajagopalan and } \\
\text { Heragu, 1997) } \text { ) }^{27}\end{array}$ & Literature review & $\begin{array}{l}\text { This paper presents an outline of } \\
\text { trends seen in layout and material } \\
\text { handling flow path design } \\
\text { research. The current trends are to } \\
\text { integrate the different aspects of } \\
\text { the manufacturing system design } \\
\text { problem. Also present an idea for } \\
\text { solving P/D (Pick-up/Drop off) } \\
\text { point location and material }\end{array}$ \\
\hline
\end{tabular}


A Literature Review on Efficient Plant Layout Design

\begin{tabular}{|c|l|l|l|}
\hline 16 & $\begin{array}{l}\text { A Classification of Different } \\
\text { Type } \\
\text { of Facility Layout Design. } \\
(\text { Taha } \text { et al, 2008) }\end{array}$ & Literature review & $\begin{array}{l}\text { handling flow path problem. } \\
\text { objectives of facility layout design, } \\
\text { flow pattern and material } \\
\text { Handling systems and finally } \\
\text { discusses the different type of } \\
\text { layout. }\end{array}$ \\
\hline 17 & $\begin{array}{l}\text { Multiple objective facility } \\
\text { layout: a heuristic to } \\
\text { generate efficient } \\
\text { alternatives. } \\
\text { (Malakooti, 1989) }\end{array}$ & $\begin{array}{l}\text { Using Heuristic and } \\
\text { metaheuristic methods } \\
\text { to solve FLP. }\end{array}$ & $\begin{array}{l}\text { Both methods find sub optimal or } \\
\text { near optimal solution have been } \\
\text { successful on some problems but } \\
\text { not on a universal level. However, } \\
\text { it is depend on decision } \\
\text { assumption made by problem } \\
\text { solver and the time required to } \\
\text { compute solution is lengthy. }\end{array}$ \\
\hline 18 & $\begin{array}{l}\text { FACOPT : A user friendly } \\
\text { Facility } \\
\text { Layout optimization System. } \\
(\text { Balakhrishnan } \text { et al, 2003) }\end{array}$ & $\begin{array}{l}\text { Comparison of genetic } \\
\text { algorithm } \\
\text { (GA) and simulated } \\
\text { annealing } \\
\text { (SA). }\end{array}$ & $\begin{array}{l}\text { The genetic algorithm model } \\
\text { performed better than the } \\
\text { simulated annealing model in } \\
\text { terms of time required to compute } \\
\text { solution. }\end{array}$ \\
\hline
\end{tabular}

\section{DISCUSSION}

Based on the literature survey as above, it is revealed that there are several studies investigated the effective design of facility planning in a production line of manufacturing process. However, there are some difficulties and limitations in finding the optimum layout configuration with general heuristic methods such as Tabu Search (TS), Simulated Annealing (SA), and Genetic Algorithms (GA). The limitations are such as time consuming and cannot get the feel of the actual setting and actual dimension of the machine and equipment in the facility design. Simulation technique is a powerful tool to asses and evaluates the possible configuration in layout optimization. According to Mc Lean and Kibira [24], simulation could be the best aid in decision making during design, analyse and improvement of manufacturing systems and computer simulation also shows great promise for raising productivity, improving product quality, shortening lead time and reducing cost in the future. Some researchers used Arena, Witness, and Pro model, which are (2D) simulation software. However, 2D view layout could not provide actual setting and actual dimension of the machine and equipment. In recent years, the development of discrete event simulation softwares grows rapidly. One of them is Flexsim software. It provides three dimensional (3D) view of the layout. This software allows designer to build virtual reality (VR) environment and can have feel of the actual setting of the factory. Potential problems such as safety issues, aisle and other layout problems can be visualized and modified by applying plant layout problem solving techniques. In the future research of some literatures, there are some new approaches of facility design analysis. One of them is combining the basic heuristic methods with 3D simulation technique in evaluating the existing layout arrangement. The objective is to create more comprehensive analysis to find the optimum layout arrangement.

\section{CONCLUSION}

In order to achieve maximum returns from the capacity of facilities, it is very essential to optimize plant layout for proposed units or re-layout of existing manufacturing 
units as per the changing market scenario. Many researchers have developed lot of models based on heuristic and meta-heuristic approach by considering different case studies. Heuristic methods such as Tabu Search (TS), Simulated Annealing (SA), and Genetic Algorithms (GA) are common tools in optimization. Limitations of those heuristic methods are time consuming and cannot get the feel of the actual setting and actual dimension of the machine and equipment. Beside the heuristic methods, simulation technique is a powerful tool used by many researchers in creating and evaluating the proposed layout design before implementation. Simulation tools that commonly used in facility planning are Arena [12], QUEST [27], IGRIP [24, ProModel [35] and Witness [31].

Looking towards the limitations of the methods discussed so far, it is revealed that the more efficient and comprehensive method can be developed by using combination of heuristic methods and simulation technique. It is also revealed that there is a scope for developing multi-objective optimization techniques particularly for small scale sectors having few departments.

\section{REFERENCES}

[1] A. Barbosa-Povoa, Richad Mateus, Augusto Q Novais, "Optimal design and layout of industrial facilities: An application to multipurpose batch plants", Industrial and engineering chemistry research, Jul 2002, DOI: 10.1021/ie010661k

[2] Ali Taghavi, Alper Murat, A heuristic procedure for the integrated facility layout design and flow assignment problem, Computer and Indusrial Engineering, 55-63, 2011 DOI: https://doi.org/10.1016/j.cie.2011.02.011

[3] Amir Sadrazadeh, "A generic algorithm with the heuristic procedure to solve the multi-line layout problem", Computers \& Industrial Engineering, 1055-1064, 2012. DOI: https://doi.org/10.1016/j.cie.2011.12.033

[4] Alvarenga, A, F. J. Gomes. N, and Mestria, M. 2000. “ M. Metaheuristic methods for a class of the facility layout problem". Journal of Intelligent Manufacturing. Vol. 11, pp 421-430. DOI: https://doi.org/10.1023/A:1008982420344

[5] Arostegui. M, Kadipasaoglu. S., Khumawala. B. 2006. An empirical comparison of Tabu Search, Simulated Annealing, and Genetic Algorithms for facilities location problems. Springerlink International journal of Production Economics 103 (2006) 742-754

[6] Askin. R. G. and Standridge. C. R., 1993, Modeling and Analysis of Manufacturing Systems, Wiley, New York.

[7] Balakhrishnan, J., Cheng, C.H., and Kam, F.W.,. 2003. FACOPT : A user friendly Facility Layout optimization System. Journal of Computers and Operation Research. Vol. 30, pp. 1625-1641.

[8] Balakrishnan. J, Cheng, C.H.; 2007. Multi-period planning and uncertainty issues in cellular manufacturing: A review and future directions, European Journal of Operational Research. Ed.177. page 281-309.

[9] Ekren, B.Y., Ornek, A.M., 2008. A Simulation based experimental design to analyze factors affecting production flow time, Simulation Modeling Practice \& Theory vol. 16, p. 278- 293

[10] Filippo De Carlo, Maria Antonietta Arlo. et.al. Layout Design for a low capacity manufacturing line: A case study, International Journal of Engineering Business Management Special Issue on Innovations in Fashion Industry (INTECH), DOI: $10.5772 / 56883$.

[11] Flexsim archieves. 2009. Flexsim simulation software-overview. Online accessed 1 September 2009. http://www.flexsim.com/products/flexsim. 
[12] Garcia, A.D., Smith, McG., 2008. Facility Planning and Design. Pearson International Edition. New York : Prentice Hall.

[13] Greasley, A. 2008. Using simulation for facility design: A case study. Elsevier International journal of Simulation Modelling Practice and Theory 16 (2008) 670-677.

[14] Hassan. M, 1994. Layout design in group technology manufacturing. Elsevier International journal of Production Economics. revised 1 July 1994. Pp 173-188.

[15] Hesen, P. M. C., Renders. P. J. J. and Rooda. J. E., 2001, Application of a Layout/Material Handling Design Method to a Furnace Area in a $300 \mathrm{~mm}$ Wafer Fab. Springerlink International journal of Advanced Manufacturing Technology 17: pp 216-220.

[16] Houshyar, A., and White, B. 1997. Comparison of solution Procedure to the Facility Layout Problem. Journal of Computers in Industrial Engineering. Vol 32, no. 1 pp. 77-78.

[17] Huang, H. 2003. Facility layout using layout modules, Ph.D. Thesis, The Ohio State University.

[18] Iqbal.M, and Hashmi. M.S.J, 2001). Design and Analysis of a virtual factory layout. Elsevier International journal of Materials Processing Technology 118 (2001). Pp 403-410.

[19] Jia Zhenyuan, LU Xiaohong, Wang Wei, et.a;., Design and implementation of lean facility layout system of a production line, International Journal of Industrial Engineering, 18,260-269,2011.

[20] K.D.Maniya, M.G. Bhatt, An alternative multiple attribute decision making methodology for solving optimal facility layout design selection problems, Computer and Indusrial Engineering ,542-549, 2011

[21] Kazi Shah Nawaz Ripon, Kyrre Glette et. al., Adaptive variable nieghbourhood search for solving multi- objective facility layout problem with unequal area facilities, Swarm and Evolutionary Computation, 2012.

[22] Lin, J.L., Foote, B., Pulat, S., Chang, C.H., and Cheung, J.Y. 1996. Solving the failure-to-fit problem for plant layout: by changing department shapes and sizes. European journal of Operation Research. Vol. 89, pp. 135-146.

[23] Malakooti, B. 1989. Multiple objective facility layout: a heuristic to generate efficient alternatives. International journal of Production Research. Vol. 27. No. 7, pp 1225-1238.

[24] McLean, C. Kibira, D. 2002. Virtual reality simulation of a mechanical assembly production line. Proceeding of the 2002 Winter Simulation Conference. Page 1130-1137.

[25] Nica, M. Lucian, Ganea, M. Donka, G. 2008. Simulation of Queues in Manufacturing Systems, Anals of the Oradea University, Fascicle of Managament and Technology Engineering, Vol. VII. Page 56-61.

[26] R. Logendran, T. Kriausakul, A Method for solving the unequal area facility layout problem using distance and shape-bassed measures, International Journal of Production Research, 1243-1272, 2007

[27] Rajagopalan. S, Heragu. S, 1997. Advances in discrete material handling system design. Sadhana, vol 22, part 2, April 1997, pp.281-292. @ printed in India.

[28] Ram D. Vaidya, Prashant N. Shende, Design and improvement of plant layout, International Journal on Theoretical and Applied Research in Mechanical Engineering (IJTARME), ISSN: 2319-3182, Volume -1, Issue-2, 2012.

[29] Richart Vazquez-Roman, M. Sam Mannan, A new trend in designing plant layouts for the process industry, ie $010661 \mathrm{k}$ 
[30] Rieth, D. Gerlach, S., 1996. Planning and controlling of fexible assembly systems for automotive industry. Proceeding of the IEEE International Symposium on Computer-aided Control System Design, Dearborn, September 1996, 15-18.

[31] Roslin. N.H, Seang.O.G., Dawal.S.Z, 2008, A study on facility planning in manufacturing process using witness. Proceeding of the 9th Asia Pasific Industrial Engineering \& Management Systems Conference. APIEMS 2008.

[32] Taha, Z. Tahriri, F. 2008. A classification of different type of facility layout design. Proceeding of Asia pacific conference on management of technology and technology entrepreneurship. Page 1-5.

[33] Tompkins, J. A., 2003. Facilities planning. New York: John Willey and Son.

[34] Xiaodan. W, Chao. C, Yunfeng. W and Dianmin, Y. 2007. Genetic algorithms for integrating cell formation with machine layout and scheduling. Springerlink International journal of Computers \& Industrial Engineering 53 (2007) 277-289.

[35] Zuhdi, A, Taha, Z. 2008. Simulation Model of Assembly System Design. Proceeding Asia Pacific conference on management of technology and technology entrepreneurship.

[36] K.Mallikarjuna, V.Veeranna and K.Hemachandra Reddy, Performance of Metaheuristic Methods for Loop Layout Design in Flexible Manufacturing System with Integrated Scheduling. International Journal of Production Technology and Management (IJPTM), 4 (1) 2013, pp. 16-22.

[37] Indranil Ghosh, An Intelligent Hybrid Multi Criteria Decision Making Technique to Solve a Plant Layout Problem. International Journal of Industrial Engineering Research and Development (IJIERD), 5 (3) 2014, pp. 13-23. 